\title{
Erenumab in chronic migraine with medication overuse
}

\section{Subgroup analysis of a randomized trial}

\author{
Stewart J. Tepper, MD, Hans-Christoph Diener, MD, PhD, Messoud Ashina, MD, PhD, Jan Lewis Brandes, MD, \\ Deborah I. Friedman, MD, MPH, Uwe Reuter, MD, Sunfa Cheng, MD, Jon Nilsen, PhD, Dean K. Leonardi, PhD, \\ Robert A. Lenz, MD, PhD, and Daniel D. Mikol, MD, PhD
}

Neurology ${ }^{\circledR}$ 2019;92:e2309-e2320. doi:10.1212/WNL.0000000000007497

\section{Abstract}

\section{Objective}

To determine the effect of erenumab, a human anti-calcitonin gene-related peptide receptor monoclonal antibody, in patients with chronic migraine and medication overuse.

\section{Methods}

In this double-blind, placebo-controlled study, 667 adults with chronic migraine were randomized (3:2:2) to placebo or erenumab (70 or $140 \mathrm{mg})$, stratified by region and medication overuse status. Data from patients with baseline medication overuse at baseline were used to assess changes in monthly migraine days, acute migraine-specific medication treatment days, and proportion of patients achieving $\geq 50 \%$ reduction from baseline in monthly migraine days.

\section{Results}

Of 667 patients randomized, 41\% $(n=274)$ met medication overuse criteria. In the medication overuse subgroup, erenumab 70 or $140 \mathrm{mg}$ groups had greater reductions than the placebo group at month 3 in monthly migraine days (mean [95\% confidence interval] -6.6 [ -8.0 to $-5.3]$ and $-6.6[-8.0$ to -5.3$]$ vs $-3.5[-4.6$ to -2.4$])$ and acute migraine-specific medication treatment days $(-5.4[-6.5$ to -4.4$]$ and $-4.9[-6.0$ to -3.8$]$ vs $-2.1[-3.0$ to -1.2$])$. In the placebo and 70 and $140 \mathrm{mg}$ groups, $\geq 50 \%$ reductions in monthly migraine days were achieved by $18 \%, 36 \%$ (odds ratio [95\% confidence interval] 2.67 [1.36-5.22]) and 35\% (odds ratio 2.51 [1.28-4.94]). These clinical responses paralleled improvements in patient-reported outcomes with a consistent benefit of erenumab across multiple measures of impact, disability, and healthrelated quality of life. The observed treatment effects were similar in the non-medication overuse subgroup.

\section{Conclusions}

Erenumab reduced migraine frequency and acute migraine-specific medication treatment days in patients with chronic migraine and medication overuse, improving disability and quality of life.

\section{Clinicaltrials.gov identifier NCT02066415.}

\section{Classification of evidence}

This study provides Class II evidence that erenumab reduces monthly migraine days at 3 months in patients with chronic migraine and medication overuse.

\author{
Correspondence \\ Dr. Tepper \\ sjtepper@gmail.com
}

\section{MORE ONLINE}

$\rightarrow$ Class of Evidence

Criteria for rating

therapeutic and diagnostic

studies

NPub.org/coe 


\section{Glossary}

$\mathbf{A E}=$ adverse event; $\mathbf{C G R P}=$ calcitonin gene-related peptide; $\mathbf{C I}=$ confidence interval; $\mathbf{C M}=$ chronic migraine; $\mathrm{eDiary}=$ electronic diary; HIT-6 = Headache Impact Test; HRQOL = health-related quality of life; MIDAS = Migraine Disability Assessment; $\mathbf{M M D}=$ monthly migraine days; $\mathbf{M S Q}=$ Migraine-Specific Quality-of-Life Questionnaire; PREEMPT = Phase 3 Research Evaluating Migraine Prophylaxis Therapy; PRO = patient-reported outcome.

Patients with chronic migraine (CM) are a difficult-to-treat population. ${ }^{1}$ In an attempt to manage their symptoms, patients with CM commonly overuse acute medications, including simple and combination analgesics, triptans, and opioids. $^{2,3}$ Such medication overuse is a risk factor for chronification $^{4,5}$ and can lead to medication overuse headache. ${ }^{6}$ Medication overuse is defined by excessive use of medications to treat acute symptoms of migraine and is not based on a diagnosis of medication overuse headache, which is a secondary headache disorder.

Patients with CM and medication overuse represent a population with a high unmet need. Debated treatment approaches include withdrawal from the implicated acute treatment, initiation of a preventive treatment, or both. ${ }^{7-9}$ It remains unclear whether migraine preventive treatments can reduce acute medication use or lower the risk of medication overuse headache.

Erenumab (in the United States, erenumab-aooe) is a fully human anti-calcitonin gene-related peptide (CGRP) receptor monoclonal antibody approved for migraine prevention ${ }^{10}$ with demonstrated clinically relevant efficacy in CM. ${ }^{11}$ CGRP is implicated in migraine pathophysiology, and its levels are elevated in CM. ${ }^{12-14}$ A 3-month pivotal trial in $\mathrm{CM}$ prevention demonstrated reduced monthly migraine days (MMD) for both 70- and 140-mg erenumab dose groups and reduced acute medication use, including migraine-specific medications (triptans, ergot derivatives). ${ }^{15}$ Here, we report the results of a planned subgroup analysis of a hard-to-treat patient population, those with and without medication overuse (a study stratification factor), using data from a pivotal study of erenumab prevention in patients with CM.

\section{Methods}

The objective of this subgroup analysis was to assess the efficacy of erenumab in patients with CM in the presence and absence of medication overuse. This study provided Class II evidence of efficacy as assessed by reduction in $\mathrm{MMD}$, reduction in acute migraine-specific medication use, and improvements in patient-reported outcomes (PROs).

\section{Patients and data source}

This was a preplanned exploratory analysis of a pivotal study that evaluated efficacy and safety of erenumab in patients with CM ( $\geq 15$ headache days per month, of which $\geq 8$ were migraine days). The eligibility criteria, design, and primary results of the parent study were previously published. ${ }^{15}$ Patients with opioid overuse ( $>12$ days during the 3 months before screening or $>4$ days during baseline) were excluded from the study, and migraine preventive drugs were prohibited during the study and 2 months before baseline. The study comprised 667 participants randomized at 69 study sites worldwide.

Patients were randomized to 1 of 3 treatment arms in a 3:2:2 ratio (subcutaneous placebo, erenumab $70 \mathrm{mg}$, or erenumab $140 \mathrm{mg}$ monthly [daily]), stratified by region (North America vs other) and medication overuse (yes or no) for a 3-month double-blind treatment phase.

This analysis used data from patients with and without medication overuse based on frequency of acute headache medication intake during the baseline period, defined with strict criteria according to International Headache Society guidelines for CM clinical trials and similar to those previously used in a study of onabotulinumtoxinA. ${ }^{16,17}$ Briefly, medication overuse was defined as use of simple analgesics (nonnarcotic analgesics such as acetaminophen or nonsteroidal anti-inflammatory drugs) for $\geq 15$ days ( $>3 \mathrm{~d} /$ wk in each week with at least 5 diary days), triptans for $\geq 10$ days ( $>2 \mathrm{~d} /$ wk in each week with at least 5 diary days), or combination therapy (any combination of triptans, ergot derivatives, analgesics, or simple analgesics with opiates or butalbital) for $\geq 10$ days $(>3$ $\mathrm{d} /$ wk in each week with at least 5 diary days) per month. This classification of medication overuse should not be interpreted as confirming a secondary diagnosis of medication overuse headache.

\section{Standard protocol approvals, registrations, and patient consents}

The study was approved by an independent ethics committee or local institutional review board at each participating site, and written informed consent was obtained from all enrolled patients. The study was conducted in accordance with the International Conference on Harmonisation Tripartite Guideline on Good Clinical Practice. This study was registered at Clinicaltrials.gov (NCT02066415).

\section{Outcome measures}

We conducted efficacy assessments throughout the baseline and double-blind phases of the study, with key assessments at month 3 (during the last month of double-blind treatment phase). Patients used a daily electronic diary (eDiary) to report information about their migraine and nonmigraine 
headaches, acute medication use, and PROs (including, Headache Impact Test [HIT-6], ${ }^{18,19}$ Migraine Disability Assessment [MIDAS; measured as 4-week recall period vs 3-month recall of standard MIDAS $]^{20}$ and Migraine-Specific Quality-of-Life Questionnaire [MSQ]). ${ }^{21,22}$ Efficacy endpoints for the subgroup analysis included changes in MMD, changes in acute migraine-specific medication days, proportion of patients achieving $\geq 50 \%$ reduction in MMD, PRO measures (MSQ HIT-6, MIDAS), and proportion of patients changing status from medication overuse to nonoveruse status. We evaluated safety by monitoring adverse events (AEs) (with MedDRA version 19.0), ${ }^{23}$ serious AEs, ${ }^{24}$ laboratory assessments, vital signs, ECGs, and anti-erenumab antibodies.

\section{Statistical analysis}

All patients who received at least 1 dose of study drug and completed at least 1 postbaseline monthly eDiary measurement were included in the intent-to-treat analysis. Descriptive summaries are provided for efficacy outcomes. Adjusted analyses of efficacy outcomes used a generalized linear mixed model including treatment, visit, treatment-by-visit interaction, region stratification factor, and baseline value as covariates and assuming a first-order autoregressive covariance structure. Values of $p$ were not adjusted for multiple comparisons. Analyses of medication overuse by visit and patient reported outcome measures by medication overuse subgroup were post hoc.

\section{Data availability}

Qualified researchers may request data from Amgen clinical studies. Complete details are available at amgen.com/ datasharing.

\section{Results}

\section{Patients}

Of 667 patients randomized, $41 \%(n=274)$ met the criteria for medication overuse. At baseline, a few differences between the medication overuse and nonoveruse subgroups were observed (table 1). The percentage of patients with prior treatment failure with at least 1 preventive treatment was higher in the medication overuse subgroup ( $75 \%$ vs $63 \%$; table 1). The mean (SD) baseline MMD was 19.0 (4.5) days in the medication overuse subgroup and 17.3 (4.6) days in the nonoveruse subgroup. Although there was almost no difference in the percentage of patients using acute headache medications, the percentage of patients using acute migrainespecific medications was higher in the medication overuse subgroup ( $92 \%$ vs $68 \%$; table 1), as was the mean number of days of monthly acute migraine-specific medication use (table 1).

\section{Outcomes}

\section{Mean MMD with and without medication overuse}

At month 3, the reduction in MMD was greater in the erenumab groups than in the placebo group in both the medication overuse and non-medication overuse subgroups (figure 1). The least-squares mean (95\% confidence interval [CI]) change from baseline in MMD in the non-medication overuse placebo group was -4.7 ( -5.5 to -3.8$)$ vs $-6.7(-7.8$ to -5.7$)$ in both the erenumab $70 \mathrm{mg}$ and $140 \mathrm{mg}$ groups, representing treatment differences of $-2.0(-3.4$ to -0.7$)$. Respective MMD changes in the medication over use subgroup were $-3.5(-4.6$ to -2.4$)$ vs $-6.6(-8.0$ to -5.3$)$ for both erenumab doses, with treatment differences of $-3.1(-4.8$ to -1.4$)$.

\section{$\geq 50 \%$ Responder rates with and without medication overuse}

The percentage of patients achieving $\geq 50 \%$ reductions in MMD was greater in the erenumab groups than in the placebo group in both the medication overuse and non-medication overuse subgroups (figure 1). In the nonoveruse subgroup, the $\geq 50 \%$ responder rates were $27 \%$ (placebo) vs $42 \%$ ( $70 \mathrm{mg}$ odds ratio [95\% CI] $1.95[1.17-3.23])$ and $46 \%$ (140 mg OR $2.25[1.36-3.74])$. In the medication overuse subgroup, the respective $\geq 50 \%$ responder rates were $18 \%$ (placebo) vs $36 \%$ (70 mg OR 2.67 [1.36-5.22]) and 35\% (140 mg OR 2.51 [1.28-4.94]).

\section{Acute migraine-specific medication use days with and without medication overuse}

Reduction in acute migraine-specific medication use days was greater in the erenumab groups than in the placebo group in both the medication overuse and nonoveruse subgroups (figure 2). Compared with a least-squares mean (95\% CI) change from baseline in acute migraine-specific medication use of $-1.2(-1.7$ to -0.8$)$ days in the non-medication overuse placebo group, the change in acute migraine-specific medication use was $-2.1(-2.7$ to -1.5$)$ days vs $-3.6(-4.2$ to $-3.0)$ days in the erenumab $70 \mathrm{mg}$ or $140 \mathrm{mg}$ groups, respectively. The treatment differences were $-0.9(-1.6$ to -0.1$)$ $(70 \mathrm{mg})$ and $-2.4(-3.2$ to -1.6$)(140 \mathrm{mg})$. The respective changes in acute migraine-specific medication use days in the medication overuse subgroup were $-2.1(-3.0$ to -1.2$)$ vs $-5.4(-6.5$ to -4.4$)$ and $-4.9(-6.0$ to -3.8$)$ with treatment differences of $-3.3(-4.7$ to -1.9$)(70 \mathrm{mg})$ and $-2.8(-4.2$ to $-1.4)(140 \mathrm{mg})$.

\section{Transition from medication overuse to nonoveruse}

Erenumab treatment reduced the number of patients with overuse of acute migraine medication intake (figure 3 and table 2). Of patients who overused simple analgesics at baseline, 60\% (15 of 25) in the $70 \mathrm{mg}$ group and $71 \%$ (24 of 34 ) in the $140 \mathrm{mg}$ group transitioned to nonoveruse status at month 3, compared with $52 \%$ ( 23 of 44 ) of patients in the placebo group. Of patients who overused triptans at baseline, $65 \%$ (61 of 94) in the $70 \mathrm{mg}$ group and 54\% (52 of 96) in the $140 \mathrm{mg}$ group changed to nonoveruse status at month 3, compared with $33 \%$ ( 42 of 127 ) of patients in the placebo group. Of patients who overused combination therapy at baseline, $45 \%$ (47 of 105) in the $70 \mathrm{mg}$ group and 59\% (66 of $112)$ in the $140 \mathrm{mg}$ group changed to nonoveruse status at 
Table 1 Demographics and baseline disease characteristics

\begin{tabular}{|c|c|c|c|c|c|c|c|c|}
\hline & \multicolumn{4}{|c|}{ Without medication overuse } & \multicolumn{4}{|c|}{ Medication overuse } \\
\hline & $\begin{array}{l}\text { Placebo } \\
\text { ( } N=169)\end{array}$ & $\begin{array}{l}\text { Erenumab } 70 \mathrm{mg} \\
(\mathrm{N}=112)\end{array}$ & $\begin{array}{l}\text { Erenumab } 140 \mathrm{mg} \\
(\mathrm{N}=112)\end{array}$ & $\begin{array}{l}\text { Total } \\
(\mathrm{N}=393)\end{array}$ & $\begin{array}{l}\text { Placebo } \\
(\mathrm{N}=117)\end{array}$ & $\begin{array}{l}\text { Erenumab } 70 \mathrm{mg} \\
(\mathrm{N}=79)\end{array}$ & $\begin{array}{l}\text { Erenumab } 140 \mathrm{mg} \\
(\mathrm{N}=78)\end{array}$ & Total $(N=274)$ \\
\hline Age, y & $40.8(11.8)$ & $41.1(11.5)$ & $42.2(11.1)$ & $41.3(11.5)$ & 43.9 (10.4) & $41.8(11.2)$ & $44.1(10.3)$ & $43.4(10.8)$ \\
\hline Female, $\mathbf{n}(\%)$ & $136(81)$ & $92(82)$ & $91(81)$ & $319(81)$ & 90 (77) & $74(94)$ & $69(89)$ & $233(85)$ \\
\hline White, n (\%) & $156(92)$ & $100(89)$ & $108(96)$ & 364 (93) & $112(96)$ & $76(96)$ & $76(97)$ & $264(96)$ \\
\hline \multicolumn{9}{|l|}{ History of prior prophylactic failure, ${ }^{\mathrm{a}} \mathrm{n}(\%)$} \\
\hline Never failed preventive medication & $57(34)$ & $46(41)$ & $43(38)$ & $146(37)$ & $29(25)$ & $18(23)$ & $21(27)$ & $68(25)$ \\
\hline Failed $\geq 1$ preventive medications & $112(66)$ & $66(59)$ & $69(62)$ & $247(63)$ & $88(75)$ & $61(77)$ & $57(73)$ & $206(75)$ \\
\hline Failed $\geq 2$ preventive medications & $79(47)$ & $48(43)$ & $52(46)$ & $179(46)$ & $63(54)$ & $45(57)$ & $40(51)$ & $148(54)$ \\
\hline Acute headache medication use at baseline, $n(\%)$ & $165(98)$ & $112(100)$ & $110(98)$ & 387 (99) & $117(100)$ & $79(100)$ & $78(100)$ & $274(100)$ \\
\hline Migraine specific & $114(68)$ & $71(63)$ & $81(72)$ & $266(68)$ & $111(95)$ & $72(91)$ & $68(87)$ & $251(92)$ \\
\hline Not migraine specific & $143(85)$ & $98(88)$ & $96(86)$ & $337(86)$ & $103(88)$ & $69(87)$ & $65(83)$ & $237(87)$ \\
\hline \multicolumn{9}{|l|}{ Baseline period } \\
\hline Monthly migraine days & $17.4(4.7)$ & $17.3(4.2)$ & $17.1(4.7)$ & $17.3(4.6)$ & $19.5(4.5)$ & $18.6(4.6)$ & $18.8(4.5)$ & $19.0(4.5)$ \\
\hline Monthly migraine attacks & $4.5(1.6)$ & $4.6(1.5)$ & $4.4(1.6)$ & $4.5(1.6)$ & $3.9(1.9)$ & $4.5(1.9)$ & $4.2(1.6)$ & $4.1(1.8)$ \\
\hline Monthly headache days & $20.4(4.1)$ & $19.9(3.7)$ & $20.2(4.0)$ & $20.2(3.9)$ & $22.1(3.5)$ & $21.3(3.8)$ & $21.5(3.5)$ & $21.7(3.6)$ \\
\hline Monthly acute migraine-specific medication use days & $6.5(6.3)$ & $6.3(6.4)$ & $7.3(6.1)$ & $6.7(6.3)$ & $13.7(7.3)$ & $12.2(6.7)$ & $13.1(6.9)$ & $13.1(7.0)$ \\
\hline
\end{tabular}


A. Without medication overuse

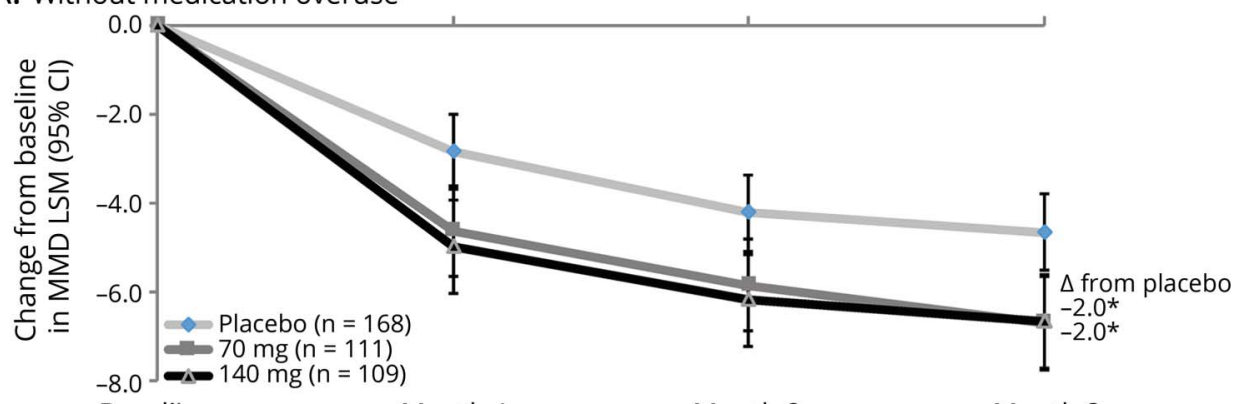

Baseline

Month 1

Month 2

Month 3

B. With medication overuse

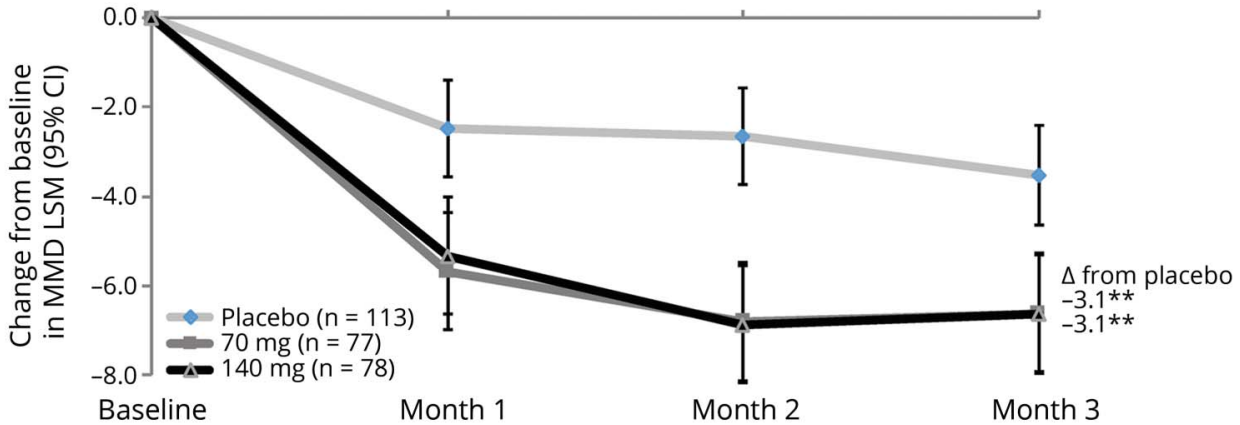

C. Without medication overuse
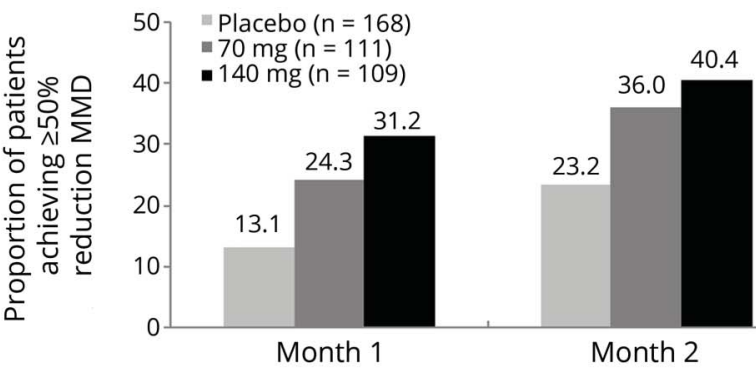

45.9

Adjusted odds ratio $(95 \% \mathrm{Cl})$ :
$70 \mathrm{mg} \quad 2.14(1.14,3.99)$
$p=0.016$
$140 \mathrm{mg} 3.00(1.64,5.49)$
$p<0.001$
$1.86(1.10,3.16)$
$p=0.020$
$1.95(1.17,3.23)$
$p=0.010$
$2.24(1.32,3.78)$
$2.25(1.36,3.74)$
$p=0.002$
$p=0.002$

D. With medication overuse

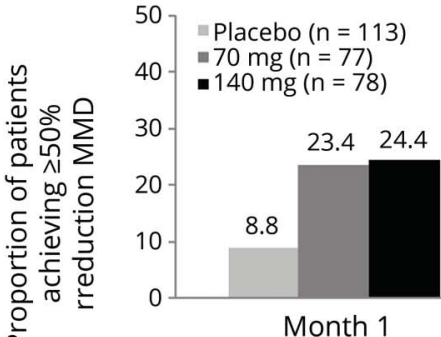

Adjusted odds ratio $(95 \% \mathrm{Cl})$

$70 \mathrm{mg} \quad 3.26(1.39,7.67)$

$p=0.005$

$140 \mathrm{mg} \begin{array}{r}3.21(1.41,7.30) \\ p=0.004\end{array}$
42.9 39.7

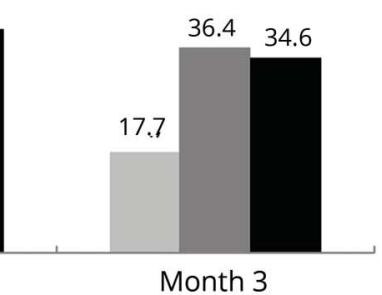

$5.31(2.59,10.91)$

$p<0.001$

$4.65(2.26,9.54)$

$p<0.001$
$2.67(1.36,5.22)$

$p=0.004$
$2.51(1.28,4.94)$
Least-squares mean (LSM) changes from baseline in monthly migraine days (MMD) in patients (A) without and (B) with medication overuse among patients with chronic migraine $(\mathrm{CM})$ who were assigned to receive placebo, erenumab $70 \mathrm{mg}$, or erenumab $140 \mathrm{mg}$ every month. Error bars represent 95\% confidence intervals (Cls) $* p<0.005, * * p<0.001$ for erenumab vs placebo. Proportion of patients (C) without and (D) with medication overuse who achieved $\geq 50 \%$ change from baseline in MMD among patients with CM who were assigned to receive placebo, erenumab $70 \mathrm{mg}$, or erenumab $140 \mathrm{mg}$ every month. 
Figure 2 Change from baseline in acute migraine-specific medication treatment days over time

A. Without medication overuse

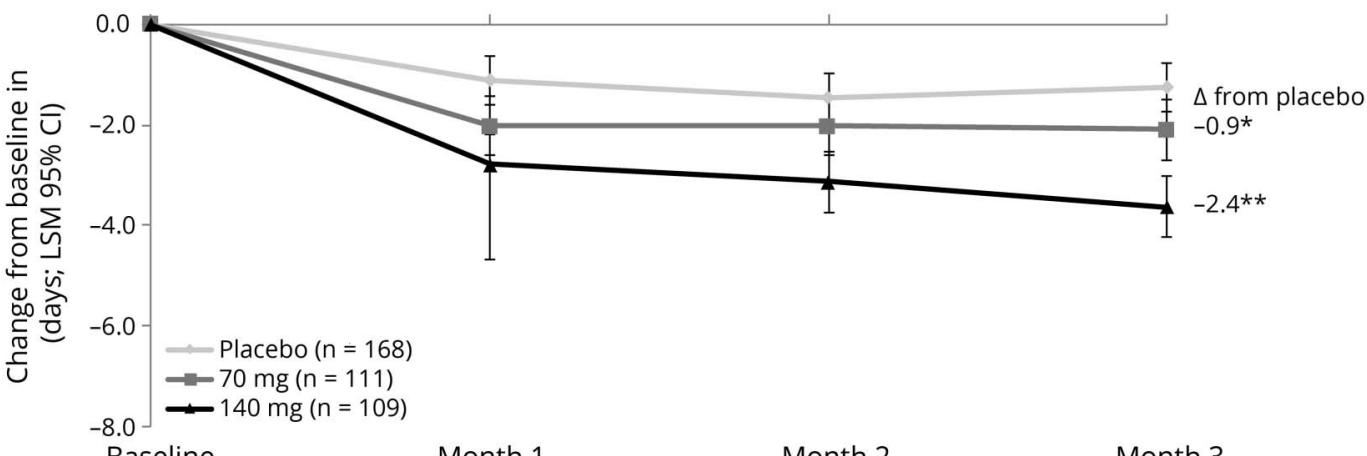

Month $1 \quad$ Month $2 \quad$ Month 3

B. Without medication overuse

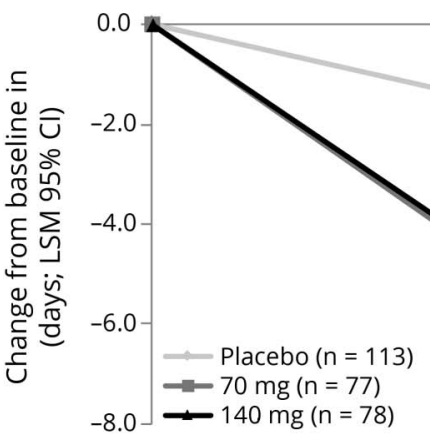

Baseline

Month 1

Month 2

Month 3

Least-squares mean (LSM) changes from baseline in acute migraine-specific medication treatment days in patients ( $\mathrm{A}$ ) without and (B) with medication overuse among patients with chronic migraine who were assigned to receive placebo, erenumab 70 mg, or erenumab 140 mg every month. Error bars represent $95 \%$ confidence intervals (Cls). ${ }^{*} p<0.05,{ }^{*} p<0.001$ for erenumab vs placebo.

month 3, compared with $40 \%$ (70 of 176) of patients in the placebo group. Similar results were found when we assessed nonoveruse status over the full 3 months or over the last 2 months (table 2). More than half of the erenumab-treated patients who overused simple analgesics or triptans at baseline switched to nonoveruse status by month 1 (table 2). Of the 35 erenumab-treated patients who switched to nonoveruse of simple analgesics by month 1, 30 (86\%) maintained nonoveruse status through all 3 months. Of the 112 erenumabtreated patients who switched to nonoveruse of triptans by month 1, 78 (70\%) maintained nonoveruse status through all 3 months. Of the 78 erenumab-treated patients who switched to nonoveruse of combination therapy by month 1, 49 (63\%) maintained nonoveruse status through all 3 months.

\section{Patient-reported outcomes}

In the both subgroups, mean reduction (improvement) from baseline in total HIT-6 score was greater in the erenumab groups compared with the placebo group (table 3 ). Treatment difference for change in HIT-6 score at month 3 exceeded the established group-level minimally important difference for HIT-6 total score ( $\geq 2.3$-point reduction). Reductions from baseline to month 3 in MIDAS total scores were greater in the erenumab groups compared with the placebo group, indicating greater improvement. Differences from baseline in MIDAS total score were $>5$ days, indicative of a clinically meaningful change. ${ }^{25}$ Health-related quality of life (HRQOL) was measured by the change in MSQ scores from baseline. At month 3, changes from baseline were greater in the erenumab groups compared with the placebo group in each MSQ domain score in the non-medication overuse subgroup and in the medication overuse subgroup (table 3). The observed between-treatment-group differences exceeded the respective minimally important difference for the MSQ Role Function-Restrictive $(\geq 3.2)$ and MSQEmotional Functioning $(\geq 7.5)$ domain scores in both the non-medication overuse and medication overuse subgroups.

\section{Adverse events}

The safety profile and AE frequency in the full patient population were previously reported. ${ }^{15}$ The frequency of AEs was similar among treatment groups and between the medication overuse and non-medication overuse subgroups, and most AEs reported were mild or moderate in severity (table 4). The most frequent AEs reported for the erenumab-treated patients ( $\geq 2 \%$ of erenumab-treated patients) were injection site erythema, muscle spasms, migraine, injection site pain, 
Figure 3 Proportion of patients with medication overuse at baseline who changed status to non-medication overuse at month 3, by acute medication category

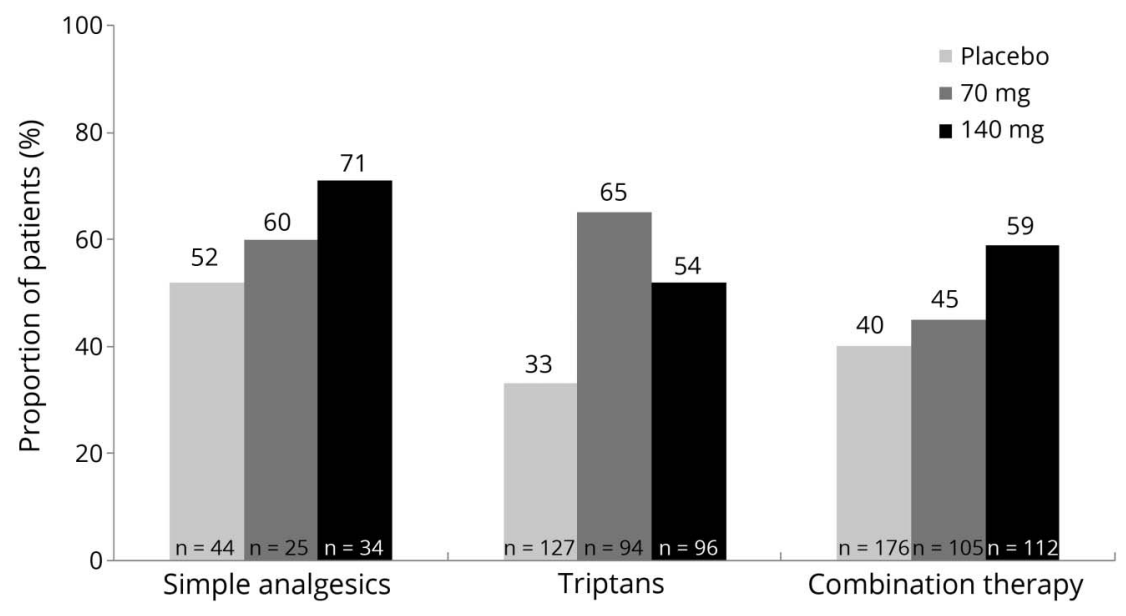

Medication overuse defined as $\geq 15$ days of simple analgesics (nonnarcotic analgesics such as acetaminophen or nonsteroidal anti-inflammatory drugs), $\geq 10$ days of triptans, and $\geq 10$ days of combination therapy (any combination of triptans, ergot derivatives, analgesics, or simple analgesics with opiates or butalbital) per month. constipation, cough, oropharyngeal pain, upper respiratory tract infection, nausea, and nasopharyngitis.

\section{Discussion}

Patients with CM who overuse acute headache medications are often difficult to treat and represent a large unmet need commonly encountered in clinical practice. Patients in this study were stratified by medication overuse on the basis of a daily eDiary completed over the 4-week baseline period in which frequency counts of acute medication intake were recorded (and should not be interpreted as having a confirmed secondary headache diagnosis of medication overuse headache). More than $40 \%$ of the patients in this study had medication overuse during the baseline period, lower than the estimated $68 \%$ to $75 \%$ of patients with CM as previously reported in a recent clinic-based study and the Phase $3 \mathrm{Re}$ search Evaluating Migraine Prophylaxis Therapy (PREEMPT) trials of onabotulinumtoxinA for CM prevention and the European topiramate CM prevention study ${ }^{3,16,26,27}$ but similar to $37 \%$ observed in the US topiramate CM prevention study. $^{27,28}$

In both the medication overuse and non-medication overuse subgroups, erenumab treatment resulted in a significant clinical response with a larger reduction in $\mathrm{MMD}$ and acute migrainespecific medication treatment days and a larger percentage of patients achieving a $\geq 50 \%$ response rate compared with placebo. The treatment differences appeared to be greater in the medication overuse subgroup than in the non-medication overuse subgroup; however, the absolute treatment effect was the same between the 2 groups. The placebo response was lower in the medication overuse subgroup, resulting in an odds ratio of achieving a $\geq 50 \%$ response comparable to or slightly higher than that of the non-medication overuse group. Even though all patients did not achieve this clinical endpoint, it is important to note that the $\geq 50 \%$ response, widely accepted by clinicians, is an arbitrary threshold and does not represent all patients who had a clinical improvement. In a separate analysis from this study, we showed that although $\approx 40 \%$ of patients achieved a $\geq 50 \%$ response, $\approx 50 \%$ to $60 \%$ achieved clinically meaningful changes in PRO scores. ${ }^{29}$ This was similar to the PREEMPT studies with onabotulinumtoxinA in which $27 \%$ of treated participants had a $\geq 5$-point reduction in HIT-6 score and a $\geq 50 \%$ reduction in headache days. ${ }^{30}$ Thus, a reduction in severity of a migraine may be sufficient to improve the quality of life for patients, which would not necessarily be reflected in the $50 \%$ responder rate data. However, even then not all patients may respond to treatments that are highly effective in other patients.

Regardless of the causal effect of medication overuse in migraine prevention, $\mathrm{CM}$ with medication overuse represents a severe form of migraine and can be difficult to treat. ${ }^{31}$ In this study, the medication overuse subgroup had a higher use of preventive medications at baseline and a higher percentage who failed to respond to 1 or 2 prior preventive treatments, indicative of a more severe subgroup of patients.

To more completely understand the clinical meaningfulness of new therapeutics for a chronic disease, it is necessary to assess outcomes of measures of efficacy, safety, and HRQOL in patients with potentially different responses to therapy. The clinical responses observed in this subgroup analysis paralleled improvements in PROs with a consistent benefit of erenumab across multiple measures of impact (HIT-6), disability (MIDAS), and HRQOL (MSQ). These data demonstrate that the rapid reductions in migraine frequency are accompanied by early improvements in ability to perform daily activities and lessened feelings of hopelessness or frustration or impact of CM. 
Table 2 Proportion of patients transitioning from medication overuse to non-medication overuse status by medication category

\begin{tabular}{|c|c|c|c|}
\hline & \multicolumn{3}{|c|}{ Medication overuse } \\
\hline & Placebo ( $N=113)$ & Erenumab $70 \mathrm{mg}(\mathrm{N}=77)$ & Erenumab $140 \mathrm{mg}(\mathrm{N}=78)$ \\
\hline Simple analgesics, N1 & 44 & 25 & 34 \\
\hline Month 1, n (\%) & $22(50.0)$ & $13(52.0)$ & $22(64.7)$ \\
\hline Month 2, n (\%) & $24(54.5)$ & $15(60.0)$ & $25(73.5)$ \\
\hline Month 3, n (\%) & $23(52.3)$ & $15(60.0)$ & $24(70.6)$ \\
\hline Over months $2-3, \mathrm{n}(\%)$ & $27(61.4)$ & $16(64.0)$ & $26(76.5)$ \\
\hline Over months 1-3, n (\%) & $25(56.8)$ & $17(68.0)$ & $27(79.4)$ \\
\hline Odds ratio $(95 \% \mathrm{Cl})$ & & $1.4(0.5-3.9)$ & $2.9(1.1-7.9)$ \\
\hline$p$ Value & & 0.59 & 0.03 \\
\hline All $3 \mathrm{mo}^{\mathrm{a}} \mathrm{n}(\%)$ & $16(36.4)$ & $11(44.0)$ & $19(55.9)$ \\
\hline Odds ratio $(95 \% \mathrm{Cl})$ & & $1.2(0.4-3.3)$ & $2.3(0.9-5.7)$ \\
\hline$p$ Value & & 0.73 & 0.075 \\
\hline Triptans, N1 & 127 & 94 & 96 \\
\hline Month 1, n (\%) & $37(29.1)$ & $58(61.7)$ & $54(56.3)$ \\
\hline Month 2, n (\%) & $38(29.9)$ & $54(57.4)$ & $57(59.4)$ \\
\hline Month 3, n (\%) & $42(33.1)$ & $61(64.9)$ & $52(54.2)$ \\
\hline Over months $2-3, \mathrm{n}(\%)$ & 43 (33.9) & $60(63.8)$ & $57(59.4)$ \\
\hline Over months $1-3, \mathrm{n}(\%)$ & $41(32.3)$ & $61(64.9)$ & $56(58.3)$ \\
\hline Odds ratio $(95 \% \mathrm{Cl})$ & & $3.9(2.2-6.9)$ & $2.9(1.7-5.1)$ \\
\hline$p$ Value & & $<0.001$ & $<0.001$ \\
\hline All $3 \mathrm{mo}^{\mathrm{a}} \mathrm{n}(\%)$ & $22(17.3)$ & $38(40.4)$ & $40(41.7)$ \\
\hline Odds ratio $(95 \% \mathrm{Cl})$ & & $3.2(1.7-6.0)$ & $3.3(1.8-6.0)$ \\
\hline$p$ Value & & $<0.001$ & $<0.001$ \\
\hline Combination, N1 & 176 & 105 & 112 \\
\hline Month 1, n (\%) & $44(25.0)$ & $32(30.5)$ & $46(41.1)$ \\
\hline Month 2, n (\%) & $58(33.0)$ & $46(43.8)$ & $54(48.2)$ \\
\hline Month 3, n (\%) & $70(39.8)$ & $47(44.8)$ & $66(58.9)$ \\
\hline Over months $2-3, \mathrm{n}(\%)$ & $58(33.0)$ & $49(46.7)$ & $67(59.8)$ \\
\hline Over months $1-3, \mathrm{n}(\%)$ & $55(31.3)$ & $48(45.7)$ & $59(52.7)$ \\
\hline Odds ratio $(95 \% \mathrm{Cl})$ & & $1.8(1.1-3.0)$ & $2.5(1.6-4.1)$ \\
\hline$p$ Value & & 0.02 & $<0.001$ \\
\hline All $3 \mathrm{mo}^{\mathrm{a}} \mathrm{n}(\%)$ & $32(18.2)$ & $17(16.2)$ & $32(28.6)$ \\
\hline Odds ratio $(95 \% \mathrm{Cl})$ & & $0.9(0.5-1.7)$ & $1.9(1.1-3.3)$ \\
\hline$p$ Value & & 0.67 & 0.03 \\
\hline
\end{tabular}

Abbreviations: $\mathrm{Cl}$ = confidence interval; $\mathrm{n}$, number of patients who converted to nonoveruser at postbaseline assessment; $\mathrm{N}=$ number of patients who received at least 1 dose of study drug and completed at least 1 postbaseline monthly electronic diary measurement; N1, number of patients who were medication overusers at baseline in the corresponding medication category; $\%=n / N 1$;.

a Patients were nonoverusers in each of the 3 months of the double-blind treatment phase. 
Table 3 Patient-reported outcomes at month 3 in patients with chronic migraine by baseline medication overuse status

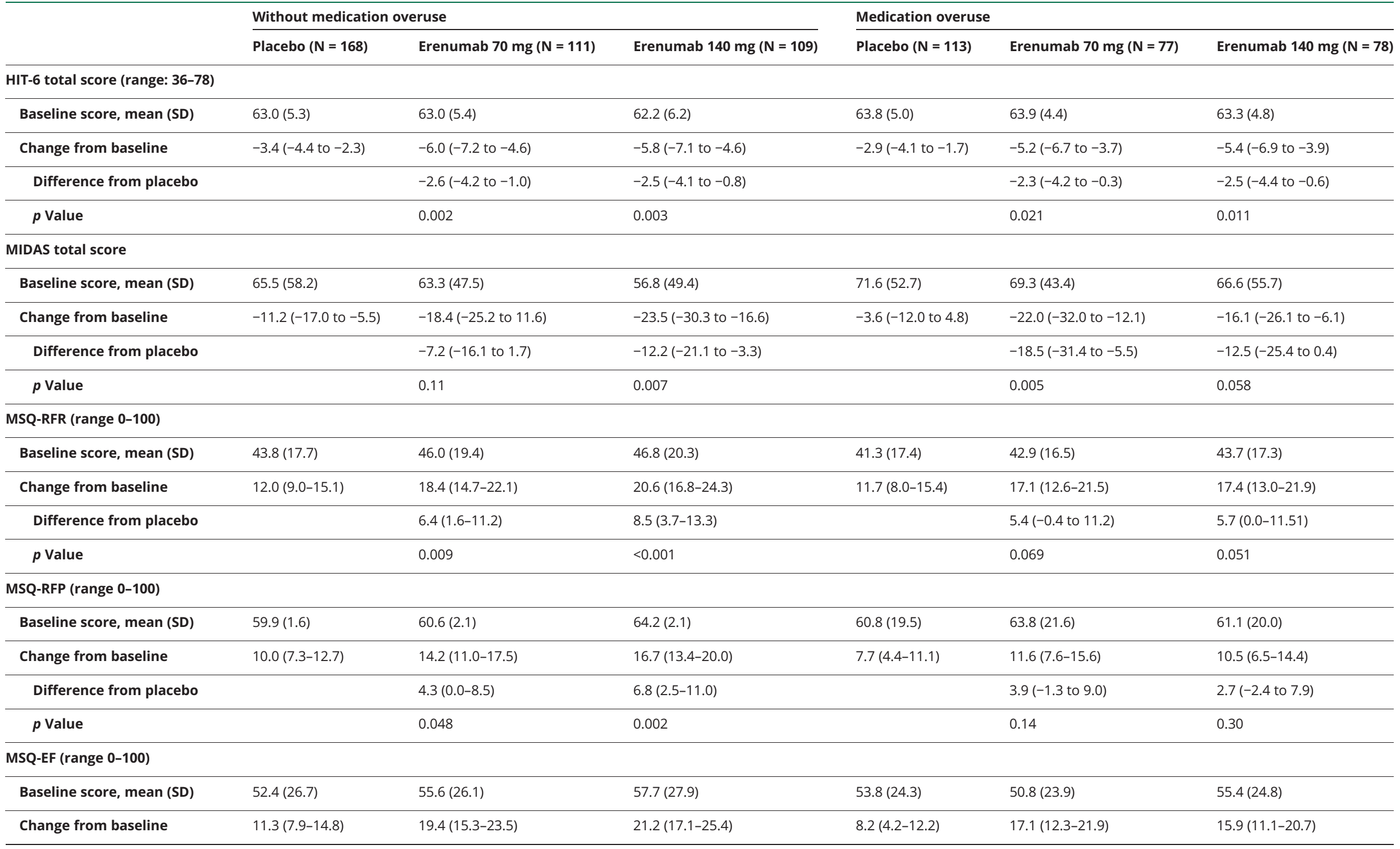


A substantial proportion of patients who overused acute medications at baseline transitioned to nonoveruse status, regardless of the type of acute medication used. There was no meaningful difference in the proportion of patients who changed status over the full course of 3 months or during the final 2 months of the double-blind phase, indicating an early reduction in acute medication use. This early switch to nonoveruse status was supported by the number of patients with nonoveruse status at month 1 . It is not known whether this is due to a decrease in the frequency of migraine days and improved HRQOL or whether it was due to high patient expectations of a new preventive treatment and reduced acute medication intake in anticipation of clinical benefit. Although not all patients changed to nonoveruse status, data from a 1-year open-label extension study with erenumab demonstrated a sustained reduction in acute migraine-specific medication treatment days in the overall population. ${ }^{32}$ However, longer-term studies may be required to confirm the durability of the effect on reduced medication overuse.

Similar to these results, previous studies have examined the effect of migraine treatments, including topiramate and onabotulinumtoxinA, in patients with $\mathrm{CM}$ and medication overuse. In the European topiramate $\mathrm{CM}$ trial, there was a significant reduction in the mean number of MMD from baseline compared with placebo within the medication overuse subgroup of patients. ${ }^{26,27}$ In the onabotulinumtoxinA analysis of pooled data from the PREEMPT trials, the efficacy results in the medication overuse subgroup were similar to those of the overall population with a significant reduction in frequency of headache days and other headache symptom measures, including PROs. ${ }^{16}$ However, the analysis of the PREEMPT data did not include an analysis of the subgroup of $\mathrm{CM}$ patients without medication overuse. These results, along with the current study of erenumab, support that, contrary to previous suggestions, headache preventive medications are not necessarily limited by acute headache medication overuse. $^{2,33}$

The $\mathrm{AE}$ and tolerability profiles in the medication overuse subgroup mirrored those observed for the full study population and were consistent with the safety and tolerability profiles observed in multiple studies with erenumab in patients with episodic and CM. ${ }^{15,34,35}$ Longer-term studies are needed not just to determine the durability of the treatment effect but also to assess long-term safety. Longer follow-up periods in large numbers of patients are necessary to detect rare AEs and to fully understand the safety profile of erenumab. Particularly for patients with medication overuse, any interactions with triptans are a concern. In vitro studies have demonstrated that erenumab did not have an additive effect on human coronary artery vasoconstriction induced by triptans. ${ }^{36}$ Furthermore, there was no effect of combination erenumab and sumatriptan on blood pressure compared to sumatriptan alone in a phase 1 study. ${ }^{37}$ These studies, in combination with the decrease in triptan use, indicate a lack of effect of erenumab on the effectiveness of triptans as acute 
Table 4 Adverse events through month 3 by baseline medication overuse status

\begin{tabular}{|c|c|c|c|c|c|c|}
\hline & \multicolumn{3}{|c|}{ Without medication overuse, $\mathrm{n}(\%)$} & \multicolumn{3}{|c|}{ Medication overuse, $\mathbf{n}(\%)$} \\
\hline & $\begin{array}{l}\text { Placebo } \\
(\mathrm{N}=168)\end{array}$ & $\begin{array}{l}\text { Erenumab } \\
70 \mathrm{mg}(\mathrm{N}=111)\end{array}$ & $\begin{array}{l}\text { Erenumab } \\
140 \mathrm{mg}(\mathrm{N}=109)\end{array}$ & $\begin{array}{l}\text { Placebo } \\
(N=113)\end{array}$ & $\begin{array}{l}\text { Erenumab } \\
70 \mathrm{mg}(\mathrm{N}=77)\end{array}$ & $\begin{array}{l}\text { Erenumab } \\
140 \mathrm{mg}(\mathrm{N}=78)\end{array}$ \\
\hline Adverse events & $71(42.3)$ & $47(42.3)$ & $50(45.9)$ & $39(34.5)$ & $36(46.8)$ & $38(48.7)$ \\
\hline \multicolumn{7}{|c|}{$\begin{array}{l}\text { Common adverse events (reported in } \geq 2 \% \\
\text { of erenumab-treated patients) }\end{array}$} \\
\hline Injection site erythema & $0(0.0)$ & $0(0.0)$ & $1(0.9)$ & $0(0.0)$ & $1(1.3)$ & $5(6.4)$ \\
\hline Muscle spasms & $4(2.4)$ & $0(0.0)$ & $2(1.8)$ & $0(0.0)$ & $1(1.3)$ & $5(6.4)$ \\
\hline Migraine & $3(1.8)$ & $1(0.9)$ & $1(0.9)$ & $0(0.0)$ & $2(2.6)$ & $4(5.1)$ \\
\hline Injection site pain & $1(0.6)$ & $4(3.6)$ & $5(4.6)$ & $2(1.8)$ & $3(3.9)$ & $2(2.6)$ \\
\hline Constipation & $1(0.6)$ & $0(0.0)$ & $4(3.7)$ & $0(0.0)$ & $0(0.0)$ & $4(5.1)$ \\
\hline Cough & $2(1.2)$ & $0(0.0)$ & $2(1.8)$ & $0(0.0)$ & $1(1.3)$ & $3(3.8)$ \\
\hline Oropharyngeal pain & $0(0.0)$ & $2(1.8)$ & $1(0.9)$ & $0(0.0)$ & $2(2.6)$ & $2(2.6)$ \\
\hline Upper respiratory tract infection & $3(1.8)$ & $5(4.5)$ & $4(3.7)$ & $1(0.9)$ & $0(0.0)$ & $2(2.6)$ \\
\hline Nausea & $2(1.2)$ & $4(3.6)$ & $4(3.7)$ & $5(4.4)$ & $0(0.0)$ & $2(2.6)$ \\
\hline Nasopharyngitis & $10(6.0)$ & $4(3.6)$ & $2(1.8)$ & $6(5.3)$ & $2(2.6)$ & $1(1.3)$ \\
\hline
\end{tabular}

Abbreviation: $\mathrm{N}=$ number of patients who received at least 1 dose of investigational product.

migraine treatment, which one would expect triptan use to increase.

Overall, these results demonstrate that erenumab is effective in patients with $\mathrm{CM}$ and medication overuse with clinical improvements in reduction of the frequency of migraines and with improvements in PROs across multiple measures of HRQOL, social and psychological impact, and disability in patients with CM.

\section{Author contributions}

S.J. Tepper, H.-C. Diener, M. Ashina, J.L. Brandes, D.I. Friedman, U. Reuter, S. Cheng, D.K. Leonardi, D.D. Mikol: interpreted the data and revised the manuscript for content. D.K. Leonardi: performed statistical analysis. R.A. Lenz: involved in design of the study, interpreted the data, and revised the manuscript for content. J. Nilsen: wrote the first draft of the manuscript based on an outline developed with all coauthors and revised the manuscript for content.

\section{Study funding}

This study was fully funded by Amgen. Erenumab is codeveloped in partnership with Amgen and Novartis.

\section{Disclosure}

S. Tepper: research grants (no personal compensation) from Alder, Allergan, Amgen, ATI, Avanir, Dr. Reddy's, electroCore, eNeura, Scion Neurostim, Teva, and Zosano; consultant and/or advisory board for Acorda, Alder, Alexsa, Allergan, Amgen, ATI, Avanir, Axsome, Charleston Laboratories, Dr. Reddy's, electroCore, eNeura, Eli Lilly, GLG,
Guidepoint Global, Kimberly-Clark, Novartis, Pernix, Pfizer, Scion Neurostim, Supernus, Teva, and Zosano; stock option from ATI; salary from Dartmouth-Hitchcock Medical Center and American Headache Society; and royalties from Springer. H. Diener: received honoraria for participation in clinical trials, contribution to advisory boards, or oral presentations from Addex Pharma, Alder, Allergan, Almirall, Amgen, Autonomic Technology, AstraZeneca, Bayer Vital, Berlin Chemie, Böhringer Ingelheim, Bristol-Myers Squibb, Chordate, Coherex, CoLucid, Electrocore, GlaxoSmithKline, Grünenthal, Janssen-Cilag, Labrys Bioloogicals, Lilly, La Roche, 3M Medica, Medtronic, Menerini, Minster, MSD, Neuroscore, Novartis, Johnson \& Johnson, Pierre Fabre, Pfizer, Schaper and Brümmer, Sanofi, St. Jude, Teva, and Weber \& Weber. Financial support for research projects was provided by Allergan, Almirall, AstraZeneca, Bayer, Electrocore, GSK, Janssen-Cilag, MSD, and Pfizer. Headache research at the Department of Neurology in Essen is supported by the German Research Council, the German Ministry of Education and Research, and the European Union. Dr. Diener serves on the editorial boards of Cephalalgia and Lancet Neurology and chairs the Clinical Guidelines Committee of the German Society of Neurology. M. Ashina: grants from Lundbeck Foundation, Research Foundation of the Capital Region of Copenhagen, Danish Council for Independent Research-Medical Sciences, and Novo Nordisk Foundation; research support from Amgen, GM-11 gamma core-R trials; consultant for Allergan, Amgen Inc, Alder, ATI, Novartis, and Eli Lilly; and advisory board for Allergan, Amgen, ATI, and Novartis. J. Brandes: research grants from Allergan, Amgen, Clinivest, Teva, Colucid, and Zozano; advisory board for 
Avanir, Supernus, and Teva; speaker's fees from Depomed, Pernix, Teva, and Avanir; and consultant fees from Amgen, Supernus. D. Friedman: research grants from Autonomic Technologies, Inc and Eli Lilly Merck; advisory board for Alder, Allergan, Amgen, Biohaven, electroCore, Eli Lilly, Supernus, Teva, Trigemina, and Zosano; and speaker's fees from Allergan, Avanir, Amgen, Supernus, and Teva. U. Reuter: consulting fees from Allergan, Amgen, Autonomic Technologies, Eli Lilly and Co, Novartis, CoLucid, and Teva; speaking/teaching fees from Amgen, Novartis, CoLucid, Pharm Allergan, and Teva; and advisory board for Amgen, Autonomic Technologies, Novartis, Pharm Allergan, and Teva. J. Nilsen and S. Cheng are employees and stockholders of Amgen Inc. D. Leonardi was an employee and stockholder of Amgen Inc at the time of the study. R. Lenz and D. Mikol are employees and stockholders of Amgen Inc. Go to Neurology.org/ $\mathrm{N}$ for full disclosures.

\section{Publication history}

Received by Neurology March 23, 2018. Accepted in final form January 16, 2019.

\section{References}

1. Silberstein S, Diener HC, Lipton R, et al. Epidemiology, risk factors, and treatment of chronic migraine: a focus on topiramate. Headache 2008;48:1087-1095.

2. Bigal ME, Rapoport AM, Sheftell FD, Tepper SJ, Lipton RB. Transformed migraine and medication overuse in a tertiary headache centre: clinical characteristics and treatment outcomes. Cephalalgia 2004;24:483-490.

3. Mathew NT. Chronic refractory headache. Neurology 1993;43:S26-S33.

4. Lipton RB, Serrano D, Nicholson RA, Buse DC, Runken MC, Reed ML. Impact of NSAID and triptan use on developing chronic migraine: results from the American Migraine Prevalence and Prevention (AMPP) study. Headache 2013;53:1548-1563.

5. Lipton RB, Diamond S, Reed M, Diamond ML, Stewart WF. Migraine diagnosis and treatment: results from the American Migraine Study II. Headache 2001;41:638-645.

6. Headache Classification Committee of the International Headache Society. In ternational Classification of Headache Disorders, 3rd Edition (Beta Version). Cephalalgia 2013;33:629-808.

7. de Goffau MJ, Klaver ARE, Willemsen MG, Bindels PJE, Verhagen AP. The effectiveness of treatments for patients with medication overuse headache: a systematic review and meta-analysis. J Pain 2017;18:615-627.

8. Diener HC, Holle D, Solbach K, Gaul C. Medication-overuse headache: risk factors, pathophysiology and management. Nat Rev Neurol 2016;12:575-583.

9. Rossi P, Faroni JV, Tassorelli C, Nappi G. Advice alone versus structured detoxification programmes for complicated medication overuse headache $(\mathrm{MOH})$ : a prospective, randomized, open-label trial. J Headache Pain 2013;14:10.

10. Aimovig (erenumab-aooe) [US package insert]. Thousand Oaks: Amgen Inc; 2018.

11. Xu C, Shi L, Rao S, et al. AMG 334, the first potent and selective human monoclonal antibody antagonist against the CGRP receptor. J Headache Pain 2014;15(suppl 1): G43. Abstract EHMTI-0315.

12. Cernuda-Morollon E, Larrosa D, Ramon C, Vega J, Martinez-Camblor P, Pascual J. Interictal increase of CGRP levels in peripheral blood as a biomarker for chronic migraine. Neurology 2013;81:1191-1196.

13. Domínguez C, Vieites-Prado A, Pérez-Mato M, et al. CGRP and PTX3 as predictors of efficacy of onabotulinumtoxin type A in chronic migraine: an observational study. Headache 2018;58:78-87.

14. Ramón C, Cernuda-Morollón E, Pascual J. Calcitonin gene-related peptide in peripheral blood as a biomarker for migraine. Curr Opin Neurol 2017;30:281-286.
15. Tepper S, Ashina M, Reuter U, et al. Safety and efficacy of erenumab for preventive treatment of chronic migraine: a randomised, double-blind, placebo-controlled phase 2 trial. Lancet Neurol 2017;16:425-434.

16. Silberstein SD, Blumenfeld AM, Cady RK, et al. OnabotulinumtoxinA for treatment of chronic migraine: PREEMPT 24-week pooled subgroup analysis of patients who had acute headache medication overuse at baseline. J Neurol Sci 2013;331:48-56

17. Silberstein S, Tfelt-Hansen P, Dodick DW, et al. Guidelines for controlled trials of prophylactic treatment of chronic migraine in adults. Cephalalgia 2008;28:484-495.

18. Dowson AJ. Assessing the impact of migraine. Curr Med Res Opin 2001;17:298-309.

19. Kosinski M, Bayliss MS, Bjorner JB, et al. A six-item short-form survey for measuring headache impact: the HIT-6. Qual Life Res 2003;12:963-974.

20. Stewart WF, Lipton RB, Dowson AJ, Sawyer J. Development and testing of the Migraine Disability Assessment (MIDAS) questionnaire to assess headache-related disability. Neurology 2001;56:S20-S28.

21. Jhingran P, Davis SM, LaVange LM, Miller DW, Helms RW. MSQ: Migraine-Specific Quality-of-Life Questionnaire: further investigation of the factor structure. Pharmacoeconomics 1998;13:707-717.

22. Jhingran P, Osterhaus JT, Osterhaus JT, Lee JT, Kirchdoerfer L. Development and validation of the Migraine-Specific Quality of Life Questionnaire. Headache 1998;38: 295-302.

23. Goux S, Vass H, Lehman C, et al. MedDRA Maintenance and Support Services Organization Annual Report 2014. 2014. https://www.meddra.org/sites/default/files/page/ documents/msso_annual_report_2014_english.pdf. Accessed April 3, 2019.

24. National Cancer Institute, National Institutes of Health, US Department of Health and Human Services. Common Terminology Criteria for Adverse Events (CTCAE), Version 4.0. NIH publication 09-7473. Published May 29, 2009; Revised June 14, 2010. http://evs.nci.nih.gov/ftp1/CTCAE/CTCAE_4.03_2010-06-14_QuickReference_5x7. pdf. Accessed March 16, 2019.

25. Lipton R, Desai P, Sapra S, Buse D, Fanning K, Reed M. How much change in headache-related disability is clinically meaningful? Estimating minimally important difference (MID) or change in MIDAS using data from the AMPP Study. Headache 2017;57:165-166. Abstract PF52.

26. Diener HC, Bussone G, Van Oene JC, et al. Topiramate reduces headache days in chronic migraine: a randomized, double-blind, placebo-controlled study. Cephalalgia 2007;27:814-823.

27. Diener HC, Dodick DW, Goadsby PJ, et al. Utility of topiramate for the treatment of patients with chronic migraine in the presence or absence of acute medication overuse. Cephalalgia 2009;29:1021-1027.

28. Silberstein SD, Lipton RB, Dodick DW, et al. Efficacy and safety of topiramate for the treatment of chronic migraine: a randomized, double-blind, placebo-controlled trial. Headache 2007;47:170-180.

29. Tepper S, Ashina M, Klatt J, et al. Erenumab impact on patient-reported outcomes in chronic migraine in presence of acute medication overuse. Headache 2018;58:160 162.Abstract PS24.

30. Dodick DW, Turkel CC, DeGryse RE, et al. OnabotulinumtoxinA for treatment of chronic migraine: pooled results from the double-blind, randomized, placebocontrolled phases of the PREEMPT clinical program. Headache. 2010;50: 921-936.

31. Scher AI, Rizzoli PB, Loder EW. Medication overuse headache: an entrenched idea in need of scrutiny. Neurology 2017;89:1296-1304.

32. Ashina M, Dodick D, Goadsby PJ, et al. Erenumab (AMG 334) in episodic migraine: interim analysis of an ongoing open-label study. Neurology 2017;89: $1237-1243$.

33. Diener HC, Limmroth V. Medication-overuse headache: a worldwide problem. Lancet Neurol 2004;3:475-483.

34. Goadsby PJ, Reuter U, Bonner J, et al. A Controlled Trial of Erenumab for Episodic Migraine. N Engl J Med 2017;377:2123-2132.

35. Sun H, Dodick DW, Silberstein S, et al. Safety and efficacy of AMG 334 for prevention of episodic migraine: a randomised, double-blind, placebo-controlled, phase 2 trial. Lancet Neurol 2016;15:382-390.

36. Rubio-Beltrán E, Labastida A, de Vries R, et al. Effects of AMG 334 on human isolated coronary artery. Cephalalgia 2016;36:1-185. Abstract.

37. de Hoon J, Van Hecken A, Vandermeulen C, et al. Phase 1, randomized, parallelgroup, double-blind, placebo-controlled trial to evaluate the effects of erenumab (AMG 334) and concomitant sumatriptan on blood pressure in healthy volunteers. Cephalalgia 2019;39:100-110. 


\section{Neurology}

\section{Erenumab in chronic migraine with medication overuse: Subgroup analysis of a randomized trial}

Stewart J. Tepper, Hans-Christoph Diener, Messoud Ashina, et al. Neurology 2019;92;e2309-e2320 Published Online before print April 17, 2019

DOI 10.1212/WNL.0000000000007497

\section{This information is current as of April 17, 2019}

\section{Updated Information \& Services}

References

Citations

Subspecialty Collections

Permissions \& Licensing

Reprints including high resolution figures, can be found at: http://n.neurology.org/content/92/20/e2309.full

This article cites 34 articles, 4 of which you can access for free at: http://n.neurology.org/content/92/20/e2309.full\#ref-list-1

This article has been cited by 4 HighWire-hosted articles: http://n.neurology.org/content/92/20/e2309.full\#\#otherarticles

This article, along with others on similar topics, appears in the following collection(s):

\section{All Clinical trials}

http://n.neurology.org/cgi/collection/all_clinical_trials

Class II

http://n.neurology.org/cgi/collection/class_ii

Migraine

http://n.neurology.org/cgi/collection/migraine

Information about reproducing this article in parts (figures,tables) or in its entirety can be found online at:

http://www.neurology.org/about/about_the_journal\#permissions

Information about ordering reprints can be found online:

http://n.neurology.org/subscribers/advertise

Neurology ${ }^{\circledR}$ is the official journal of the American Academy of Neurology. Published continuously since 1951, it is now a weekly with 48 issues per year. Copyright Copyright (C) 2019 The Author(s). Published by Wolters Kluwer Health, Inc. on behalf of the American Academy of Neurology.. All rights reserved. Print ISSN: 0028-3878. Online ISSN: 1526-632X.

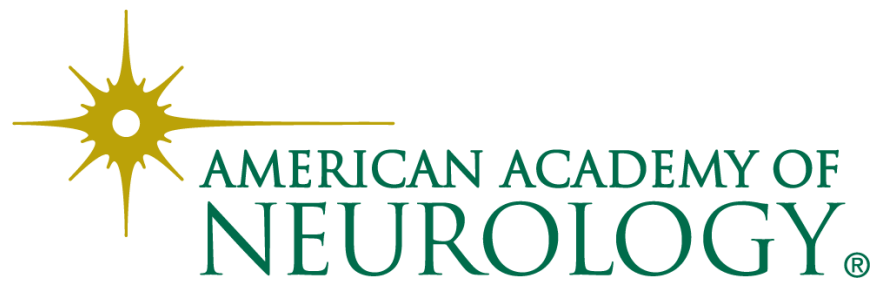

